\title{
SZÉKELYUDVARHELYI VÁROSI KÖNYVTÁR
}

Székelyudvarhelyi Városi Könyvtár

Cím: Székelyudvarhely, Kőkereszt tér 2.

Honlap: https://biblioudv.ro

E-mail: biblioudv@yahoo.com

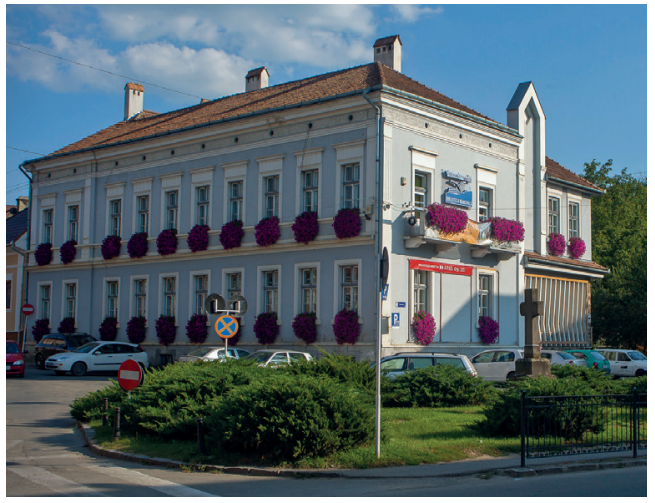

Nehéz volna megmondani, hogy mikor létesült városunk első közösségi használatra szánt könyvtára, de a gyökerek mindenképpen messzire nyúlnak. A „Székely Támadt” vár helyén múködő domonkosrendi (vagy ferencrendi) zárda tekintélyes építmény volt, amelyet az 1490-es évek kezdetén Báthori István vajda rövid idő alatt várrá tudott alakíttatni. A zárda - már csak méreteinél fogva is - mindenképpen kellett, hogy a szertartáshoz, a szerzetesek képzéséhez (közös és egyéni olvasás formájában) rendelkezzen kisebb könyvtárral. Ez hangsúlyozott módon valószínűsíthető a jezsuiták 16. század végén létrehozott udvarhelyi kolostorára, amely 1593-tól kezdődően egy középfokú tanintézet fenntartását is biztosította. A jelenleg több mint 77000 kötetet számláló Tudományos Könyvtár az egykori Református Kollégium könyvtárának az utóda, amely az iskola alapításától kezdődően formálódott. Három ősnyomtatvány (incunabulum), több száz, a 16. század második feléből származó könyv, régi magyar könyv, hungarica, kézirat, több ezer 18-19. századi kötet, folyóirat, iskolai értesítő adja e gyűjtemény felbecsülhetetlen értékét.

A 19. század második felében megjelentek a városban a polgári jellegú közkönyvtárak. Ilyen könyvtárral bírt az 1872-ben létrejött Polgári Olvasókör, az 1875-ben alakult Nőegylet, az 1887-től működő Kereskedő Ifjak Olvasó Egylete, az 1880-ban életre hívott Ipari Önképző és Segélyegylet. Egy 1895-ből származó feljegyzés szerint a helyi polgári "Cassino" öt szobás kényelmes helyiséggel, olvasóteremmel, számos újsággal rendelkezett.

Az 1951-ben alakult városi könyvtár e polgári könyvtárak szellemi utódjának tekinthető.

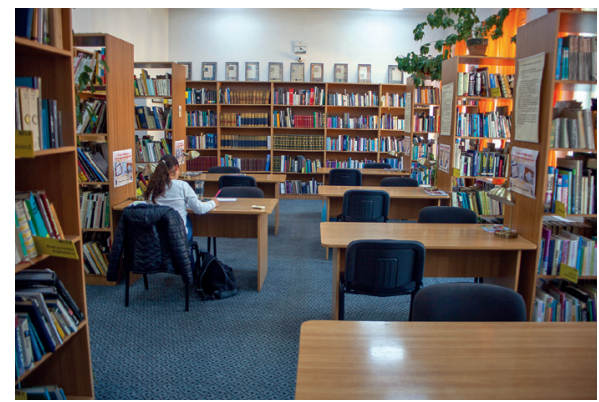




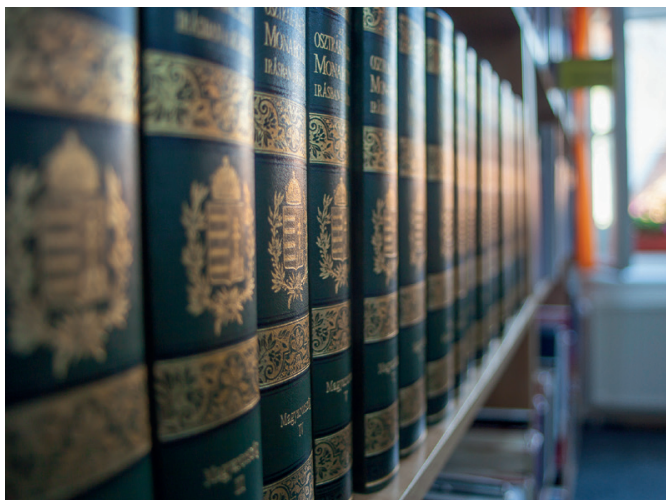

Első igazi otthonát 1958-ban nyerte el a Művelődési Ház emeletén, majd miután ez szúkössé vált, 1988-ban a Kossuth utca 23. alatti egykori banképületbe költözött. A tulajdonjogi problémák, a gyarapodó állomány nyomán kialakult zsúfoltság lassan szinte lehetetlenné tette az itteni működést. A városi önkormányzat több éves keresése után 1996-ban döntött az egykori „Szabó Károly vendéglö” könyvtárrá való átépítése mellett.

Az építkezés 2000-ben, az átköltözés és berendezkedés 2001 februárjában fejeződött be. 2001. február 19-től a régió legkorszerűbb könyvtára várja olvasóit Székelyudvarhelyen, amelyben a hagyományos könyvtári szolgáltatások mellett számtalan közösségformáló, tudomány-népszerűsítő, tartalmas szórakozást és kikapcsolódást biztosító közművelődési program kapott helyet, úgy a gyerekek, mint a felnőttek számára.

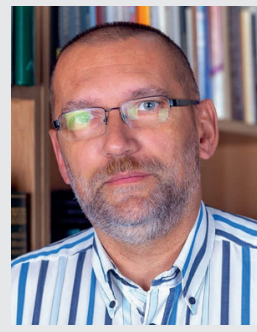

\section{Szőcs Endre}

1999-ben az egri Eszterházy Károly Tanárképző Főiskolán szerzett földrajz tanári diplomát, majd 2005-ben a kolozsvári Babeș-Bolyai Tudományegyetem geográfus végzős hallgatója volt. 2010-ben kulturális menedzseri képesítést szerzett. 14 év pedagógiai munka után, 2002-ben a Hargita Megyei Kulturális Központ, majd 2007-től szintén a megyei önkormányzathoz tartozó Hargita Megyei Hagyományőrzési Forrásközpont munkatársa volt. A Székelyudvarhelyi Városi Könyvtárban 2013-tól dolgozik. 